\title{
The Role of Teachers in Increasing Student Motivation on Learning Indonesian Language
}

\author{
Marwanto \\ IAIN Salatiga \\ E-mail: marwanto@iainsalatiga.ac.id
}

How to cite (in APA Style): Marwanto. (2020). The role of teachers in increasing student motivation on learning Indonesian language. Jurnal Pendidikan Babasa dan Sastra, Vol. 20(2), 273-284. doi: https://doi.org/10.17509/bs_jpbsp.v20i2.33066

Article history: (Received: 9 April 2020, Revised: 1 July 2020, Accepted: 1 Sept 2020)

Journal homepage: http:// ejournal.upi.edu/index.php/BS_JPBSP

\begin{abstract}
This study discusses the role of the teacher in increasing student motivation in learning Indonesian. The teacher is a very important figure in the teaching and learning process as a mediator, facilitator, and leader in the class. Teachers and students must be able to communicate well as the principle of communication between teacher and students so that learning goes well. The focus of this research is how the teacher's role in increasing student motivation towards learning Indonesian in Muhammadiyah Plus Salatiga Elementary School. This study uses a questionnaire or questionnaire technique with a population of 53 teachers and 30 subjects or half of the subjects. The results found that Muhammadiyah Primary School Plus Salatiga always improves good communication as the principle of communication between teachers and students so that learning runs well. As mediation, facilitators, and leaders make Muhammadiyah SD teachers fully responsible for the progress and improvement of the scientific insights of their students. Teachers must always be able to encourage and invite joy in the learning process. Motivation is a must so that students enjoy learning and being in class.
\end{abstract}

Keywords: The role of the teacher; teacher; motivation; learning

\section{Peran Guru dalam Meningkatkan Motivasi Siswa pada Pembelajaran Bahasa Indonesia}

\begin{abstract}
Abstrak: Penelitian ini membahas tentang peran guru dalam meningkatkan motivasi belajar siswa dalam pembelajaran bahasa Indonesia. Guru merupakan sosok yang sangat penting dalam proses belajar mengajar sebagai mediator, fasilitator, dan pemimpin di kelas. Guru dan siswa harus mampu berkomunikasi dengan baik sebagai prinsip komunikasi antara guru dan siswa agar pembelajaran berjalan dengan baik. Fokus penelitian ini adalah bagaimana peran guru dalam meningkatkan motivasi belajar bahasa Indonesia siswa di SD Muhammadiyah Plus Salatiga. Penelitian ini menggunakan teknik angket atau angket dengan populasi 53 guru dan 30 mata pelajaran atau separuh dari mata pelajaran. Hasil penelitian menemukan bahwa SD Muhammadiyah Plus Salatiga selalu meningkatkan komunikasi yang baik sebagai prinsip komunikasi antara guru dan siswa agar pembelajaran berjalan dengan baik. Sebagai mediasi, fasilitator, dan pimpinan menjadikan guru-guru SD Muhammadiyah bertanggung jawab penuh untuk kemajuan dan peningkatan wawasan keilmuan siswanya. Guru harus selalu dapat menyemangati dan mengundang kegembiraan dalam proses pembelajaran. Motivasi adalah suatu keharusan agar siswa menikmati belajar dan berada di kelas.
\end{abstract}

Kata kunci: Peran guru; guru; motivasi; pembelajaran 


\section{INTRODUCTION}

Indonesian is an important communication tool or medium in Indonesia. As a medium of communication, language bridges citizens to interact, talk to each other, and talk to each other, especially for those who are separated by differences in their respective regional languages. Indonesian has a big role in people's lives. In community communication, especially Javanese society which is divided into ethnic groups requires Indonesian to communicate with each other. For example, communication between ethnic groups in Javanese society, Javanese society with Sundanese people, Sundanese with Betawi people, or communication with the people of Sumatra, Sulawesi, Kalimantan, Papua, and others. It takes a unifying language, namely Indonesian to make it easier to communicate. Because of its very important role, Indonesian must always be taught, familiarized, developed, and preserved. Who should protect, of course, language speakers, Indonesian citizens?

We know that the Indonesian language has played a major role in unifying the nation, especially since it was progressed in the youth oath on October 28, 1928. The spirit and spirit of nationalism grew at that time to form and create a spirit of national unity. This spirit must always be cultivated and developed thorough proficiency in the Indonesian language.

From an early age, Indonesian should always be introduced by parents as a medium of communication even though it is still in a simple form. Currently, the introduction of the Indonesian language has started from early childhood education, even with the development of the era demands that children who are still young must have learned Indonesian vocabulary through curriculum-standard care and care. However, the real learning begins when the child reaches the primary school level. Teachers play an important role in teaching Indonesian here. Starting with simple communication, vocabulary, types of words, and inviting communicative talk with students using Indonesian. This is very necessary and important, especially for educators or teachers so that students can use Indonesian as a means or medium of communication in their daily lives, both at school and at home. This is reflected in the Indonesian language whose position as a function of language, namely as a medium of communication, a means of selfexpression, a means of self-control, and the media where social integration and adaptation is achieved (Finoza, 2005, p.2).

Learning the Indonesian language is something that must be given in schools, starting from elementary school should be a strong foundation for the first basic education and subsequent education. Schools must provide adequate Indonesian language skills so that students gain proficiency in the Indonesian language. Students already have control over the learning process, the role of the teacher is needed during the learning exploration process (Tjakradidjaja, Prabandari, Prihatiningsih, dan Harsono, 2016, pp. 7884). As teachers, of course, they experience something challenging when they have to teach at the elementary school level, so teachers are required to always be sensitive to that situation.

The learning objective is to evaluate students' abilities in cognitive, affective, and psychomotor aspects of subjects in elementary schools (Afandi, Chamalah, \& Puspita, 2013, p.3). The objectives of learning Indonesian include educating students and the public to be able to communicate using Indonesian, respect and feel proud, be able to understand, appreciate, and use it in life (Wintala, 2015, p.21). All of it aims to make students have language proficiency, just as the goal of language proficiency aims at communicating with community members clearly and regularly (Kerap, 1993: p.10). The essence of Indonesian language learning is the process of learning to understand and produce ideas, feelings, messages, information, data, and knowledge 
for various purposes of scientific communication, literature, work, and daily communication, both written and oral (Anna, 2016, p.76).

Based on the above opinion, it can be concluded that learning is educating, inviting, and teaching communication to students. While the purpose of learning is to educate, invite, and evaluate students' abilities, while the purpose of learning Indonesian is to educate and invite students to always be proud and use Indonesian in everyday life in communication.

Law No. 20 of 2003 concerning the National Education System states that education is a conscious and planned effort to create an atmosphere of learning and the learning process so that students actively develop their potential to have religiousspiritual strength, self-control, personality, intelligence, noble character, and skills that they need, society, nation, and state (Wijanarko, 2017, p.52). Education has an important role in efforts to improve national intelligence. Education must become a demand and obligation for the nation to improve the quality of education itself.

The teacher must always be able to give enthusiasm and invite joy in the learning process. Motivation is a must so that students enjoy learning and being in class. Motivation is someone's encouragement to do something to achieve his goals (Fauziah, Rosnaningsih, \& Azhar, 2017, p.48). Motivation creates students' seriousness in learning and achieving what they aspire to. Motivation itself is divided into two, namely intrinsic motivation (referring to internal factors both in the task itself and in students) and extrinsic motivation (referring to factors from outside and applied to tasks or students by teachers or others) (Davies, 1991).

As a teacher, when learning must be able to arouse students' enthusiasm for learning, foster enthusiasm for dreaming of ideals, provide stimulation in the form of gifts, and direct students to good behavior. The benchmarks for the role of the teacher in the student learning process are (1) learning planning; (2) implementing learning programs; (3) personal relationships with students; (4) learning innovation, and (5) evaluation (Hamzah, 2007, p.23).

Muhammadiyah Plus Salatiga elementary school comes with a vision and mission to become a center of excellence in the IMTAQ (faith and piety) and Science and Technology fields with national characteristics and cares for the environment trying to make it happen through education that is oriented towards skill and character development. Various programs concentrate on developing students' talents and interests. Hospitality is shown every day, both to students and parents, and the environment. Faith and piety development is carried out every day starting from entering with the introduction of greetings and greetings, reading the Quran, Duba prayer, Dubur prayer, and tabfidz, exstra. Science and technology are also a balance in achieving IMTAQ. Achievements at the city, provincial, national, and international levels can be achieved.

Teachers of SD Muhammadiyah Plus are young and energetic teachers. They are always ready to innovate and have a passion for progress in increasing the potential for professionalism as a teacher. In its development, SD Muhammadiyah Plus has become a place of reference, examples, and a place for comparative studies for schools in Indonesia, and many schools have even entrusted their teachers to learn about the habituation carried out at SD Muhammadiyah Plus Salatiga.

As teachers are also not left behind in improving IMTAQ and science and technology, various training is carried out, various kinds of achievements can also be achieved, as principals with outstanding achievements at the national, provincial level, and various other competitions. The symbol of intelligent children with noble character is implanted in students, including in teaching teachers also showing 
politeness. Even the school's achievement was also shown by winning first place as a character school at the city level of Salatiga. The Elementary School Muhammadiyah Plus campus itself (another name for SD Muhammadiyah Plus) is located in Dukuh, Sidomukti Sub-district, Salatiga City. Located in a complex area of $4000 \mathrm{~m} 2$ and a school environment, SD, SMP, SMA, and SMK in the Sidomukti Salatiga sub-district or a strategic educational environment, but far from the city crowd. Meanwhile, in the morning and afternoon, there is quite a lot of traffic because the times for leaving and returning from school take place. Parents are proud and happy to send their children to school because of the friendly atmosphere, both the teachers, the environment, and the service. To be able and get to school at SD Muhammadiyah Plus Salatiga, parents have to submit birth certificates for their children at SD Muhammadiyah Plus Salatiga one year earlier because of the limited classes, while the enthusiasts usually reach 3 times more than what is received. Several previous studies discuss the role of teachers in the Indonesian language learning process, namely Idzhar's (2016) research on the Role of Teachers in Increasing Student Motivation (Idzhar, 2016). This research contains motivation in learning to produce maximum learning. Similar to Arianti (2018) entitled The Role of Teachers in Increasing Student Motivation, explores teacher motivation to be able to make students creative and active (Arianti, 2018). Meanwhile, Sumiati (2018) examines teacher motivation in the form of professional service, humanitarian, and social services (Sumiati, 2018).

Role of Teachers in Managing Teaching Learning Situation (Malik, Murtaza, \& Khan, 2011). This research is limited to science teachers and students studying science subjects in class $\mathrm{X}$ in three governments. Teachers' Role as Facilitator in Learning (Jagtap, 2015). This research uses the role of the teacher as a facilitator in learning. the role of teachers in learning development (Zein, 2005) and research on the role of teachers in learning (Khairunnisa, 2017). Both studies discuss the role of teachers in general in learning development. Furthermore, research on the roles of teachers and students in Indonesian language learning is based on a communicative approach (Patiung, 2017). Similar research on the role of teachers in the Indonesian language learning process was also carried out (Dasem, Laka, \& Niwele, 2018). The purpose of this study is to describe how the role of teachers in increasing student motivation towards learning Indonesian at Muhammadiyah Elementary School Plus Salatiga.

\section{METHODS}

This study aims to answer how the teacher's role in increasing student motivation towards learning Indonesian at Muhammadiyah Elementary School Plus Salatiga. This research is a quantitative descriptive. The population in this study were 60 teachers of SD Muhammadiyah Plus Salatiga, while the subjects of this study used 30 teachers of SD Muhammadiyah Plus Salatiga, or half of them were taken. The method used in this research is using a questionnaire or questionnaire technique, observation, and documentation.

\section{RESULTS AND DISCUSSION}

\section{The Role of the Teacher}

Teachers are people who teach, usually as a job at a school or similar institution (Setiawan, n.d, 2012-2019). The teacher is an educator. As an educator, of course, he plays an active role in creating a good teaching and learning process. A teacher has a tremendous responsibility for the success and learning process in class. The proverb of the teacher digugu lan ditiru (people who are trusted and followed) was imitated not only for words, but it has become a reality. All commands and what the teacher does are examples that are easy for students to do and implement. Jagtap suggests that teachers as facilitators use 
active learning methods in class and will improve their abilities as teachers (Jagtap, 2016: p.3903).

Currently, teachers are experiencing development as facilitators in classroom learning, especially in elementary schools. They must teach as well as guide students from reading, writing, and learning to speak. Teachers must always compile their lesson plans so that they can provide a pleasurable attraction for students or it can be said that a teacher is considered successful if they can satisfy and please students and also for themselves (Esmaeili, Mohamadrezai, \& Mohamadrezai, 2015,p.1). This means that the teacher's job is not only to teach and spend subject matter, but teachers must understand and concentrate on the four pillars of education, namely learning to live, learning to know, learning to do, and learning to be (Jagtap, 2016: p.3903).

A teacher is not only silent but must be able to understand some of the subjects taught in elementary school and must also educate the students' morals to be better. There are four stages of interaction between teachers and students, namely, the builder of addiction, the motivator's guide, the involved facilitator, and the independent consultant (Grow, 1991).

Seeing its very important role, a teacher must be able to carry out his role in the teaching and learning process. The role of the teacher in the teaching and learning process is to educate children by providing direction and motivation, providing facilities, media, adequate learning experiences, and helping develop aspects of student personality (Ahmadi \& Supriyanto, 1991). This means that teachers must be the right media for the development of students' thoughts and morals in schools and be a good role model for student growth and development both at school and in their homes.

\section{The Role of Teachers in Indonesian Language Learning}

Teachers have a very big role in designing the success of learning (Setyawati, 2015, p.165). Almost eight hours a day students are with the teacher, and vice versa, maybe even more than that. Teachers are the second parents of children. Sometimes a child or student follows what is ordered by the teacher more than the parents themselves. So a teacher deserves to always be a companion who is polite and has a noble character. The leadership style shown must show attitudes and traits that are wise and appropriate to be followed by role models for their students. Teachers must be able to be friends as well as mediate for the development of student learning. It is universally recognized that teachers have become the backbone of any education system as knowledge is transferred from teacher to student (Malik et al., 2011, pp.783-833).

Teachers must always innovate so that they can produce smart, creative, independent, and responsible students. Able to organize the class so that the class is alive, meaning that there is good communication between teachers and students or vice versa between students and teachers. Teachers must have classroom management skills, be able to develop student potential, be aware of and respond to student needs, and understand and master strategies to solve student problems in class (Dasem et al., 2018, pp.126-136). There are several roles as a teacher, namely, (1) lesson planning; (2) implementing learning programs; (3) personal relationships with students; (4) learning innovation, and (5) evaluation (Hamzah, 2007, p.23).

Teachers will be aware of their role as facilitators, teachers will use active learning methodologies, actively learn classroom techniques, and project-based learning (Jagtap, 2016: p.3903). Teachers are also referred to as managers. As teachers must play an active role in teaching, as stated by Ramsey (1999), the effective role of managers is to create a climate that welcomes, supports, and values 
innovative thinking and problem solving (Ramsey R.D., 1999). The teacher plays an active role in creating a conducive atmosphere in the classroom.

\section{The Role of Teachers in Increasing Student Motivation}

Teachers must be able to improve and awaken students in learning. Providing positive stimulation so that students are influenced and willing to continue learning both at school and home without being forced. Teachers must be able to arouse students' enthusiasm for learning and provide motivation for learning development and exemplary in the classroom. One of the teacher's activities to increase student motivation in learning, namely being diligent in facing assignments, being resilient in facing difficulties, being independent, not being bored, being able to defend opinions, and being happy to find and solve problems (Sumiati, 2018, pp.145164). Meanwhile, another opinion says that to foster student motivation through prizes, giving numbers, mutual competition, ego, giving tests, knowing results, exams, punishment, desire to learn, and interest (Arianti, 2018, pp.117-134).

Teachers can increase or arouse student enthusiasm, awakening students, direct students, encourage students, and build personal closeness with students so that students can be more open if they have problems in learning. Providing exemplary and being able to be a good pioneer for student learning.

\section{The role of the Teachers of Muhammadiyah Elementary School Plus Salatiga in increasing student motivation towards learning Indonesian \\ SD Muhammadiyah Plus Salatiga} (Muhammadiyah Elementary School Plus Salatiga) has 53 teachers and 18 employees. Male teachers were 12 or $22,64 \%$, while female teachers were 41 or $77,36 \%$. The results of observations made on teachers at SD Muhammadiyah Plus Salatiga about the role of teachers in the Indonesian language learning process using benchmarks conveyed by Hamzah (2007), namely (1) lesson planning; (2) implementing learning programs; (3) personal relationships with students; (4) learning innovation, and (5) evaluation (Hamzah, 2007, p.23). Based on these five components, it is hoped that they will be able to become a measure for teachers of SD Muhammadiyah Plus Salatiga in improving the quality of learning and at the same time helping students to improve their proficiency in Indonesian.

The teacher is a very important figure in the teaching and learning process as a mediator, facilitator, and leader in the classroom. Teachers and students must be able to communicate well as the principle of communication between teachers and students so that learning runs well. As mediation, facilitators, and leaders make Muhammadiyah SD teachers fully responsible for the progress and enhancement of the scientific insights of their students. Mediation provides a way and facilities for students to continuously develop themselves by providing stimuli or stimuli to learning. However, sometimes teachers of SD Muhammadiyah Plus Salatiga also act as facilitators, especially for grades 1 to 3 . Its function is of course to make it easier for children to develop in learning their knowledge. Meanwhile, leaders in the class are teachers of SD Muhammadiyah who are required to be leaders who can provide good role models or examples for their students. To differentiate activities for students that have not or have never been carried out in the homes of each student, apply the vision of students who are intelligent and have noble cha

Validity and reliability tests are carried out to measure the extent to which the data is valid and reliable. The validity test states that the instrument used in obtaining data is used or not. According to Sugiyono, the data is valid means that the instrument can be used in research measurement (Sugiyono, 2010). In this study, the validity test was carried out using 
SPSS version 20 which resulted in $\mathrm{R}$ count $>\mathrm{R}$ table, so that the decision to test the validity was declared valid.

Furthermore, Sugiyono stated that reliability is the degree of data consistency within a certain time interval (Sugiyono, 2010). Based on the table that has been processed using SPP version 20, the Cronbach s alpha value is 0.763 . This means that it is greater than the $\mathrm{r}$ table, so the questionnaire is declared reliable or consistent.

\section{Normality test}

To test the extent to which the teacher's role in increasing student motivation towards learning Indonesian at Muhammadiyah Elementary School Plus Salatiga uses statistical tests using the SPSS program version 20 . The test results from statistical data processing are as follows:

\begin{tabular}{|c|c|c|c|c|}
\hline & & $P G$ & PPB & \begin{tabular}{|l|} 
Unstand \\
ardized \\
Residual
\end{tabular} \\
\hline \multirow{3}{*}{ PG } & $\begin{array}{l}\text { Pearson } \\
\text { Correlation }\end{array}$ & 1 & -221 & \\
\hline & Sig. (2-tailed) & & .241 & 1.000 \\
\hline & $\mathrm{N}$ & 30 & 30 & 30 \\
\hline \multirow{3}{*}{ PPB } & $\begin{array}{l}\text { Pearson } \\
\text { Correlation }\end{array}$ & & & $.975^{* *}$ \\
\hline & $\begin{array}{l}\text { Correlation } \\
\text { Sig. (2-tailed) }\end{array}$ & $\begin{array}{l}.221 \\
.241\end{array}$ & & .000 \\
\hline & & 30 & 30 & 30 \\
\hline \multirow{3}{*}{$\begin{array}{l}\text { Unstand } \\
\text { ardized } \\
\text { Residual }\end{array}$} & $\begin{array}{l}\text { Pearson } \\
\text { Correlation }\end{array}$ & .000 & .975 & \\
\hline & Sig. (2-tailed) & $\begin{array}{l}1.00 \\
0\end{array}$ & .000 & \\
\hline & $\mathrm{N}$ & 30 & 30 & 30 \\
\hline
\end{tabular}

Teachers have a very big role in designing successful learning (Setyawati, 2015, p.165). Based on the Sig. (2-tailed) from the output table above, the Sig. (2tailed) between the teacher's role and the Indonesian language learning process is $0.000<0.05$, which means that there is a significant correlation between the teacher's role variable and the Indonesian language learning process. Based on the guidelines for taking the Correlation Coefficient interpretation, the relationship is stated to be very strong with a correlation coefficient of 0.975 . This is supported by research
(Idzhar, 2016), (Sumiati, 2018), and (Arianti, 2018).

Meanwhile, to arouse student motivation in learning according to what Davies said. He applies it to arousing students with motivation, namely intrinsic motivation (referring to internal factors both in the task itself and in students) and extrinsic motivation (referring to factors from outside and applied to tasks or students by teachers or others) (Davies, 1991).

1. Intrinsic motivation.

The motivation that comes from within students, can come from school 
elements such as teachers, friends, and the school environment. When students enter the school the teachers greet them with smiles, greetings, and greetings. This activity is routinely carried out to welcome students happily. Even the principal and his staff came down to greet students and guardians every morning. SD Muhammadiyah Plus Salatiga implements a habituation program consisting of routine and programmed habituation. Routine habits include: 1) saying greetings and shaking hands, 2) dhuba prayer, 3) recitation of the Quran, 4) praying in congregation dhubur, 5) disposing of garbage in its place, 6) caring for plants, 7) praying before and after eating, and pray before and after studying. This is evidence of the closeness of the teacher to student.

To maintain student closeness. Teachers at SD Muhammadiyah Plus Salatiga are not provided with teacher room facilities, this is solely so that they can always be close to their students at all times, from attending until students return home. The principal's room is not a haunted space for students to come and enter and they often use the principal's room as a preparation practice area if there is a competition. Students of SD Muhammadiyah Plus Salatiga are always on good terms with each other. No status differentiates one another. One another provides mutual support in any activity. In every competition, anyone who departs and represents SD Muhammadiyah Plus Salatiga at any level is always supported by others. The teachers felt proud of each child even though they were not the representatives. The environment of SD Muhammadiyah Plus Salatiga is an environment that is conducive to student learning. So that it can provide comfort and safety.

2. Extrinsic motivation.

The motivation that comes from outside of school, can be the home environment such as parents, and the environment outside the school. Good communication and opened as widely as possible for the student guardian to convey criticism and suggestions through the class group WhatsApp. Information is also opened as widely as possible to find out the condition of the child at school by the parents of the student. Every lesson that is carried out at school is always reported through social media to the student's guardian.

On another occasion, once a month parenting is held to foster the closeness of the guardians, students, and teachers of SD Muhammadiyah Plus Salatiga. SD Muhammadiyah Plus Salatiga happens to have a conducive environment. Far from urban areas, but at the heart of education in Salatiga.

Trust and safety are proven by prospective students who have been registered one year before the school registration period takes place. This proves the great trust of the residents and the school environment. In welcoming this support, SD Muhammadiyah invited prospective students half a year earlier which was called school observation. This activity introduces prospective students to the environment, teachers, and at the same time motivates the importance of school.

In learning Indonesian, schools, and teachers apply communication in Indonesian. Teachers in teaching and communicating always use Indonesian. This is used as a general teaching standard in the world of education that teaching at SD Muhammadiyah Plus Salatiga uses Indonesian as a medium of communication between teachers and students and vice versa between students and teachers. This reference is by the function of language as a medium of communication and the function of language, namely as a means of communication in the world of education. 
The benchmarks used are (1) lesson planning; (2) implementing learning programs; (3) personal relationships with students; (4) learning innovation, and (5) evaluation (Hamzah, 2007, p.23) which are described as follows,

\section{1) Learning Planning}

SD Muhammadiyah Plus Salatiga implements Saturday Coordination Meeting for the implementation of the next week's meeting. At this meeting discussing the preparation of learning and things that need to be prepared in the learning process. Besides, every Monday morning the class coordinator teachers will always gather to discuss learning that morning and so on. The media makes it easy for the coordinators to convey the results of the morning coordination meeting to the class teachers.

\section{2) Implementation of learning programs}

Muhammadiyah Elementary School Plus Salatiga City implements a half-day program, namely KBM (Teaching and Learning Activities) lasts until 14.00 WIB. Furthermore, to increase academic and non-academic potential, this elementary school organizes extracurricular activities from 14.00 to $16.00 \mathrm{WIB}$.

\section{3) Personal relationships with students}

Teachers of SD Muhammadiyah Plus Salatiga have close relationships with students. This is evidenced by constantly communicating and teaching something polite to students. Every morning the teachers and principals greet the students together with smiles, greetings, and greetings, even the teachers also help open the vehicle doors to welcome the students. Teachers are not provided with teacher room facilities so that they can always be close to their students at all times, from attending until students return home. The principal's room is not a haunted space for students to come and enter and they often use the principal's room as a preparation practice area if there is a competition. Good communication and opened as widely as possible for the student guardian to convey criticism and suggestions through the class group WhatsApp.

\section{4) Learning innovation}

The skills and exemplary of the Principal of SD Muhammadiyah Plus in Salatiga City show innovative, effective, and unique behavior in managing the institution, especially its teaching staff. To bring comfort to educators, improve student achievement in academics and non-academics and be able to bring the name of the school to be the school most in demand by the community.

\section{5) Evaluation}

SD Muhammadiyah Plus Salatiga applies an evaluation system, namely direct, weekly, semester, and annual evaluations. Daily evaluation is carried out on the same day after finishing the lesson. Each level will gather according to their respective levels. The level is the same as the grade level. For example, level 1 means that all grade 1 teachers under the coordinator will do the evaluation together. What has been achieved, has not been achieved, and what can be concluded in the learning. Weekly evaluation is always done on Saturday. Together they will gather at each level and will discuss what has been done one week before and also plan to learn activities the following week. Likewise, the semester and annual evaluations are generally carried out jointly at all levels. Except for level 6 because it was intended during learning. 


\section{CONCLUSION}

Muhammadiyah Primary School Plus Salatiga always improves good communication as the principle of communication between teachers and students so that learning runs well. As mediation, facilitators, and leaders make Muhammadiyah SD teachers fully responsible for the progress and improvement of the scientific insights of their students. Teachers must always be able to encourage and invite joy in the learning process. Motivation is a must so that students enjoy learning and being in class. To generate student motivation in learning according to what Davies said, namely intrinsic motivation and extrinsic motivation. Meanwhile, in everyday communication using Indonesian between teachers and students and between students and teachers as the function of Indonesian as a communication in the field of education.

\section{REFERENCES}

Afandi, M., Chamalah, E., \& Puspita, O. W. (2013). Model dan Metode Pembelajaran di Sekolah (Pertama). Semarang: Unissula Press.

Ahmadi, A., \& Supriyanto, W. (1991). Psikologi Belajar. Jakarta: Rineka Cipta.

Anna, H. (2016). Pembelajaran Bahasa Indonesia dalam Konteks Multibudaya. Al-Ta'dib, 9(1), 74-91.

Arianti. (2018). Peranan Guru Dalam Meningkatkan Motivasi Belajar Siswa. Didaktika Jurnal Pendidikan, 12(2), 117-134.

Dasem, A. A., Laka, B. M., \& Niwele, A. (2018). Peranan Guru Dalam Proses Pembelajaran Bahasa Indonesia Di SD Inpres Komboi Kabupaten Biak Numfor. Wacana Akademika, 2, 126-136.
Davies, I. K. (1991). Pengelolaan Belajar. Jakarta: Rajawali Pers.

Esmaeili, Z., Mohamadrezai, H., \& Mohamadrezai, A. (2015). The Role of Teacher's Authority in Students ' Learning. Education and Practice, 6(19), 1-16.

Fauziah, A., Rosnaningsih, A., \& Azhar, S. (2017). Hubungan antara Motivasi Belajar dengan Minat Belajar Siswa Kelas IV SDN Poris Gaga 05 Kota Tangerang. JPSD, 4(1).

Finoza, L. (2005). Komposisi Bahasa Indonesia untuk Mahasiswa Nonjurusan Babasa (Pertama). Jakarta: Diksi Insan Mulia.

Grow, G. O. (1991). Teaching Leaners to be Self-Directed. Adult Education Quarterly, 41 (3), 129-149.

Hamzah, B. U. (2007). Profesi Kependidikan. Jakarta: Bumi Aksara.

Idzhar, A. (2016). Peranan Guru Dalam Meningkatkan Motivasi Belajar Siswa. Jurnal Officer, 2(2).

Jagtap, P. (2016). Teachers Role as Facilitator in Leaning. Scholl Research Journals (SRJIS), 3, 3903-3905.

Kerap, G. (1993). Komposisi (Sebuah Pengantar Kemabiran Berbahasa) (9th ed.). Jakarta: Ikrar Mandiri Abadi.

Khairunnisa. (2017). Peranan Guru dalam Pembelajaran. Prosiding Seminar Nasional Tahunan Fakultas Ilmu Sosial UN Medan 2017, 413-416.

Malik, M. A., Murtaza, A., \& Khan, A. majeed. (2011). Role of Teachers in Managing Teaching Learning Situation. Contenporary Research Business, 3(2), 783-833.

Patiung, D. (2017). Peran Guru dan Siswa dalam Pembelajaran Bahasa Indonesia Berbasis Pendekatan Komunikatif di SMA Negeri 1 Sesean Kabupaten Toraja Utara. 
Fakultas Tarbiyah Dan Keguruan UIN

Makasar, VI, 12-13.

Ramsey R.D. (1999). Lead, Follow or Get out of the way. California: Growing Press inc.

Setiawan, E. (n.d.). (2012-2019). Kamus Besar Bahasa Indonesia Kamus versi online/daring). Versi 2.B. Jakarta: Badan Pengembangan dan Pembinaan Bahasa, Kemdikbud (Pusat Bahasa).

Setyawati, R. (2015). Peran Guru Bahasa dan Sastra Indonesia dalam Pembelajaran yang Inovatif. Buana Sastra, (2), 165-174.

Sugiyono. (2010). Metode Penelitian Pendidikan. Bandung: Alfabeta.

Sumiati. (2018). Peranan Guru Kelas Dalam Meningkatkan Motivasi Belajar
Siswa. Tarbawi Jurnal Pendidikan Islam, 3(2), 145-164.

Tjakradidjaja, F. A., Prabandari, Y. S., Prihatiningsih, T. S., \& Harsono. (2016). The Role of Teacher in Medical Student Self-Directed Learning Process. Educational and Learning, 10, 78-84.

Wijanarko, Y. (2017). Model Pembelajaran Make a Match untuk Pembelajaran IPA yang Menyenangkan. Taman Cendekia, 01(01), 52-59.

Wintala, S. A. (2015). Bahasa dan Sastra Indonesia (Pedoman Praktis Menulis dalam Bahasa Indonesia) (Pertama). Yogyakarta: Araska.

Zein, M. (2005). Peran Guru dalam Pengembangan Pembelajaran. $V, 274$ 285. 
